\title{
The potential of silymarin for the treatment of hepatic disorders
}

\author{
Claus Hellerbrand ${ }^{1}$, Jörn M. Schattenberg ${ }^{2}$, Philipp Peterburs ${ }^{3}$, Anja Lechner ${ }^{3^{*}}$ and Reto Brignoli ${ }^{4}$
}

\begin{abstract}
Silymarin has long been used as a hepatoprotective remedy. Chronic toxicity studies in rodents have confirmed that silymarin has a very low toxicity. These data support its history as a safe medication in hepatic diseases. In the last years, several studies expanded our understanding of the pharmacology of silymarin and its molecular mechanisms of action. These new insights may affect the handling of silymarin in clinical studies and daily practice. Additionally, scientific knowledge in hepatology is constantly evolving with, particularly, an increase in the field of non-alcoholic fatty liver disease which is considered today as the most frequent liver disease worldwide. In this review, we will describe scientific evidence for the effectiveness of silymarin in hepatic disorders. We will focus on silymarin's pharmacological effects in non-alcoholic fatty liver disease and on its well described effects in alcoholic liver disease and acute intoxications, e.g. with Amanita species. We will discuss the relevance of pharmacological data as a function of doses or concentrations required for a given effect and of concentrations achieved in the target tissues. Many pharmacological effects of silymarin can be attributed to effects downstream or upstream of its antioxidative and membrane-stabilizing properties. However, despite promising new experimental and clinical data further clinical studies are required including long-term observations and the application of hard clinical endpoints such as survival rates, to further support silymarin's use for the treatment of hepatic diseases.
\end{abstract}

Keywords: Silymarin, Pharmacology, Safety, Liver disease, Non-alcoholic fatty liver disease

\section{Introduction}

Carduus marianus, Silybum marianum, or milk thistle is an edible Mediterranean herbal with a very long history as medicinal plant. Probably, this practice was also supported by the religious connotations of its name (e.g. chardon marie, Mariendistel, Saint Mary's thistle, etc.). The currently employed standardized milk thistle extracts made from the fruits contain 30-65\% silymarin as active ingredient. Silymarin is a complex mixture of polyphenolic molecules, including seven closely related flavonolignans, i.e. silibin A, silibin B, isosilibin A, isosilibin $B$, silichristin, isosilichristin, silidianin and the flavonoid taxifolin, the most effective antioxidant of these molecules [1]. Silymarin administered per os has become a frequently applied therapy for various liver disorders. Silymarin is classified by the WHO Anatomical Therapeutic Chemical (ATC) classification system as liver

\footnotetext{
* Correspondence: anja.lechner@bionorica.de

${ }^{3}$ Bionorica SE, Kerschensteinerstraße 11-15, 92318 Neumarkt, Germany Full list of author information is available at the end of the article
}

therapy (A05BA03). Approved indications are described as toxic and inflammatory liver diseases although at low doses it is also recommended for dyspepsia.

Due to chronic alcohol abuse and modern live style liver disease continues to be a major health concern and the search for new but also the optimization of known agents for the therapy of liver diseases are still of great importance. According to the World Health Organization (WHO), alcohol is the third largest risk factor for premature mortality, disability and loss of health. Importantly, alcoholic liver disease is responsible for the majority of alcohol-related deaths [2, 3]. At the same time, nonalcoholic fatty liver disease (NAFLD) is emerging as an even larger health problem and NAFLD is considered today as the most common liver diseases worldwide. The prevalence of NAFLD in the general population of Western countries is up to $30 \%$, and a significant number of these individuals are developing non-alcoholic steatohepatitis (NASH) which may progress to liver cirrhosis and hepatocellular carcinoma (HCC). Already today, NASH is

\section{Springer}


reported to be the third most common indication for liver transplantation in the United States [4, 5]. A large proportion of patients with NAFLD have a co-existing metabolic syndrome with symptoms like central obesity, dyslipidemia and insulin resistance. These patients have a major risk factor for cardiovascular diseases [6]. In Europe the estimated prevalence rate of NAFLD is up to $30 \%$ in the general population (including obese children) and up to $70 \%$ in people with type 2 diabetes. These conditions [7] generate large direct costs, loss of productivity and income and poor health-related quality of life [8].

In addition to the above mentioned life styledependent liver disorders, viral infections, i.e. hepatitis B virus (HBV) and hepatitis $\mathrm{C}$ virus $(\mathrm{HCV})$ infections, are causing chronic liver disease. A predominant decline in prevalence of HBV infections was achieved with implementation of vaccine programs and mandatory screenings of blood donors improved HCV management in most countries. However, the WHO estimates that with large geographical variations - two to three percent of the world's population are still infected with $\mathrm{HCV}$. This results in a total number of 120 to 170 million $\mathrm{HCV}$ infected people that also carry a high risk to develop liver disease, i.e. liver cirrhosis and HCC [9]. Antiviral therapy applies nucleoside analogs and interferonalpha and targets viral replication as well as anti-viral immune responses, i.e. activation of $\mathrm{T}$ cells and modulation of innate immune cells [10]. Due to its antiviral properties in vitro [11] silymarin had been considered a promising additional candidate for the treatment of acute infection with HBV and HCV. However, little or no benefit was shown in clinical trials $[12,13]$. The long-term effects in the treatment of chronic $\mathrm{HCV}$ as an additive to for example nucleoside analogues or interferons remains to be assessed $[14,15]$ and will not be further discussed in this review.

The complexity of the liver explains that one single pharmacological intervention is unlikely to cause a major functional change by itself unless it touches a very specific 'bottle neck' in a chain of events. Nutrients absorbed through the gut are transported to the liver through the portal vein blood flow. Hepatic function is regulated by blood-derived hormones, cytokines and adipokines. Additionally, intestinal hormones and transmitters of the vegetative nervous system exert a strong influence on the liver. Different cell types among which hepatocytes are most abundant are involved in the control of immunity and inflammation. Stellate cells that can transform into myofibroblast-like cells upon activation are centrally involved in the fibrotic response observed in chronic liver disease. Fibrosis contributes to the ability of hepatocytes to regenerate after injury or resection [16]. An additional player in liver disease is the gut microbiome. The complex interaction of the gut flora with the intestinal immune system effects the development of a phenotype of liver disease both in mice as well as in patients $[17,18]$.

During the last 20 years our understanding of liver diseases and their treatment has undergone a remarkable evolution. Therefore, we aimed to reassess the current perception of silymarin within this changing environment. In 2014, about 200 articles dealing with silymarin - among those 8 clinical reports - have been published, reflecting the continued interest in this plant extract. Preclinical data exhibit potent antiinflammatory, antifibrotic, antiviral, and antioxidative properties of silymarin [19]. However, the predictive value of animal and in vitro models is sometimes misleading and may have led to failures of translation into the clinical practice for many years [20]. A classic example was the aforementioned role of silymarin in chronic viral hepatitis [11-13]. Not all of the published studies fulfill high scientific standards. Once we cite studies with less clear-cut scientific evidence in this review, we describe the limitations and focus on the bits of evidence which may fit or not into a logical puzzle of the current scientific knowledge with respect to silymarin [20]. Furthermore, to be of clinical interest, experimental data on silymarin should be obtained at doses and administration routes comparable to those used in clinical settings. Moreover, there should be evidence that silymarin reaches effective concentrations in the target organ or tissue.

Going through this review, the reader will have to take into account the anatomical and functional complexity of the liver, i.e. experimental or clinical data will always just shed light on some partial aspects of the pathophysiology or show some final outcome without providing a complete insight about how this came to be [21, 22].

\section{Review}

Search strategy and methods are described in the Additional file 1.

\section{Toxicology}

Silymarin has been known for its very low toxicity, but the picture has recently been enlarged by an important chronic toxicity study which added some new data on neoplasias. Toxicological data are crucial for the calculation of the therapeutic index, i.e. the ratio of the highest exposure of the drug that results in no toxicity to the exposure that produces the desired effect, and risk benefit assessment of a drug.

\section{Acute toxicity}

Acute toxicity studies of silymarin after intravenous infusion have been carried out in mice, rats, rabbits and dogs. The $\mathrm{LD}_{50}$ values were $400 \mathrm{mg} / \mathrm{kg}$ in mice, $385 \mathrm{mg} /$ $\mathrm{kg}$ in rats, and $140 \mathrm{mg} / \mathrm{kg}$ in rabbits and dogs though 
these values were dependent on infusion rate. With slow infusion rate (over 2 to $3 \mathrm{~h}$ ) the $\mathrm{LD}_{50}$ increased to $2 \mathrm{~g} / \mathrm{kg}$ in rats and after oral administration it was even $10 \mathrm{~g} / \mathrm{kg}$ [23].

\section{Chronic toxicity}

The large safety margin of silymarin was shown in the "milk thistle report NTP TR 565" [24, 25]. The investigators gave feed containing $12,500,25,000$, or 50,000 parts per million $(1.25 \%, 2.5 \%$, or $5 \%)$ of milk thistle extract to groups of 50 male and female rats and mice for two years. At the end of the experiments there was no incidence for toxicity comparing the survival of treated animals with the untreated controls. There was also no incidence for the development of cancers.

\section{Genetic toxicity}

Some milk thistle constituents yield a positive Ames test [26]. However, having not shown any indication of carcinogenicity in animal studies, silymarin extracts are currently considered as non-carcinogens (HMPC Genotoxicity Guideline) [24, 26]. With silymarin, but not silibinin, the Ames test was positive in S. typhimurium strains TA98 and TA100, when testing occurred with liver S9 activation enzymes. Administration of milk thistle extract in feed for 3 months did not increase the frequencies of micro-nucleated normochromatic erythrocytes, an indication of chromosomal abnormalities, in the peripheral blood of mice $[24,26]$.

\section{Human safety}

In blinded clinical trials the overall incidence of adverse events was $2.4 \%$ (similar to placebo) while in open trials the incidence of adverse events was $1 \%$. The most common adverse event associated with silymarin use is a laxative effect; other symptoms include nausea, epigastric discomfort, arthralgia, pruritis, and urticaria. Considering all published randomized trials, uncontrolled studies, and case reports, only one serious adverse event has been considered related to silymarin (diarrhea, vomiting, and collapse in a 57 year old woman) [27].

\section{Pharmacokinetics}

Silymarin is a non-lipophilic, poorly water soluble $(0.05 \mathrm{mg} / \mathrm{mL})$ mixture of flavonolignans; it is transported bound to serum albumin as the carrier protein [28]. Table 1 summarizes the pharmacokinetic parameters of silymarin in human healthy volunteers [29-31].

Interestingly, the disease status has been shown to have a major impact on the pharmacokinetics of silymarin. After a single oral dose of $600 \mathrm{mg}$, the $\mathrm{C}_{\max }$ and AUC of plasma concentrations for total silymarin flavonolignans were 2.4- to 4.7-fold higher in patients compared to healthy volunteers [29, 32]. For example, mean AUC ${ }_{0-24 h}$ was two times higher in HCV patients without cirrhosis, or four times higher in patients with cirrhosis and three times higher in patients with NAFLD. Only NAFLD subjects showed evidence of enterohepatic cycling of flavonolignans which may support the efficacy of silymarin in this indication. At an oral dose of $560 \mathrm{mg}$ of silymarin and comparing with non-cirrhotic $\mathrm{HCV}$ subjects, NAFLD subjects had blood $\mathrm{AUC}_{0-48}$ values for silybin $A$ and silybin B which were 1.5-fold and 2.1-fold greater, respectively, than found in healthy controls. Elimination half-lives were similar between the disease groups (range 1.1-1.5 h), whereas $\mathrm{T}_{\max }$ was delayed by $1 \mathrm{~h}$ in NAFLD patients, suggesting that a reduced silymarin metabolism may cause the differences in drug exposure between NAFLD and HCV subjects [32]. In conclusion, pharmacokinetic data implicate a strong correlation between the state of liver damage and bioavailability of silymarin.

A group of non-cirrhotic patients with chronic $\mathrm{HCV}$ infection received oral doses of $140,280,560$, or $700 \mathrm{mg}$ silymarin every $8 \mathrm{~h}$ for 7 days. No drug-related adverse events were observed. With a 5 -fold increase in dose, the steady-state exposures for silybin A and silybin B increased 11-fold and 38-fold, respectively, suggesting non-linear pharmacokinetics. These findings suggest that low bioavailability associated with customary doses of silymarin may be overcome with doses above $700 \mathrm{mg}$ three times a day (tid) [33].

Referring to the tissue distribution of silymarin it can be concluded from different studies in patients with colorectal carcinoma and studies in mice [34] that the highest tissue [35] concentration was found in the colon [36] whereas the lowest concentration was detected in the brain and the prostate [35, 37]; the liver tissue had concentrations similar as found in

Table 1 Summary of pharmacokinetic parameters of silymarin in the human body [29-31]

\begin{tabular}{|c|c|c|c|c|}
\hline $\mathrm{T}_{\max }$ & $\begin{array}{l}\text { Plasmatic half life } \\
\text { (non-conjugated) }\end{array}$ & $C_{\max }$ (oral dose of $600 \mathrm{mg}$ ) & Metabolism & Excretion \\
\hline \multirow[t]{3}{*}{$1.0-3.7 \mathrm{~h}$} & $1-3,2 \mathrm{~h}$ & \multirow{3}{*}{$\begin{array}{l}53.1 \mathrm{ng} / \mathrm{ml} \text { (free flavonolignans) } \\
84.3 \mathrm{ng} / \mathrm{ml} \text { (sulphated silymarin) } \\
168 \mathrm{ng} / \mathrm{ml} \text { (glucoronidated silymarin) }\end{array}$} & \multirow{3}{*}{$\begin{array}{l}\text { Phase II metabolitessulphates, } \\
\text { glucorinide, diglucorinides }\end{array}$} & \multirow[t]{3}{*}{ via bile and urine } \\
\hline & (conjugated) & & & \\
\hline & $3.3-7.9$ h & & & \\
\hline
\end{tabular}


the blood. This might be explained by the main absorption of silymarin by the GI tract and its low bioavailability.

\section{Interactions}

In spite of a fairly large amount of studies dedicated to these potential problems, no clinically relevant interactions between silymarin and other drugs have been identified upon administration in the recommended customary doses. In the following, some key elements are highlighted.

\section{Silymarin}

Silymarin, silibinin A, and silibinin $\mathrm{B}$ at high concentrations significantly inhibited Organic AnionTransporting Polypeptides (OATP)-mediated estradiol$17 \beta$-glucuronide and rosuvastatin uptake into human hepatocytes. However, calculation of the maximal unbound portal vein concentrations/ $/ \mathrm{IC}_{50}$ values indicated a low risk for silymarin-drug interactions in hepatic uptake with a customary silymarin dose. Higher than customary doses of silymarin, or formulations with improved bioavailability, might increase the risk of flavonolignan interactions with OATP substrates in patients [38]. In Chinese volunteers, the coadministration of silymarin $140 \mathrm{mg}$ tid during 2 weeks with talinolol, a typical substrate of multidrug resistance (MDR1) P-glycoprotein, led to an increase of the plasmatic AUC of the later by $36 \%$ [39].

Several studies dealt with cytochrome P450 induction in primary human hepatocytes and for cytochrome P450 inhibition with human liver microsomes. For the currently employed doses, drug-drug interactions are possible for CYPs $2 \mathrm{C} 8$ and $2 \mathrm{C} 9$, but not likely, and are remote for CYP 2C19, 2D6, and 3A4 [40-42].

\section{Silibinin}

Silibinin A and silibinin B were reported to inhibit CYP2C9 in human liver microsomes using the clinically relevant probe $(\mathrm{S})$-warfarin at possibly therapeutic concentrations. These observations combined with the high systemic silibinin concentrations suggested a potential warfarin-milk thistle interaction [43]. However, a proof-of-concept clinical study showed only minimal interaction between a high-dose of silibinin in combination with both midazolam (CYP3A and (S)-warfarin 9 and $13 \%$ increase in AUC, respectively) [44].

\section{General pharmacology}

Observations in the 1980ies suggested that silymarin and its components are incorporated into the hydrophobic-hydrophilic interface of the microsomal bilayer, affecting the packing of the acyl chains and restoring the membrane fluidities of liver microsomes and mitochondria [45, 46]. Already some years earlier it has been reported that silymarin "might exert stabilizing effects at the membrane level, by virtue of its action upon membrane-bound enzymatic activities" [47]. Silymarin appears to act as an antioxidant not only because it acts as a scavenger of the free radicals that induce lipid peroxidation, but also because it influences enzyme systems associated with glutathione and superoxide dismutase, mainly by increasing the expression and activation of the nuclear transcription factor (erythroid-derived 2)-like 2 factor (Nrf2) [48, 49]. At high concentrations, silymarin consistently increases the hepatocellular plasma membrane stability in vitro [50].

Lipid peroxidation is attributed to be one of the major mechanisms leading to degeneration of cell membranes and the development of liver disease. Under those conditions the hepatoprotective effects of silymarin appear to depend mainly on five properties:

- activity against lipid peroxidation as a result of free radical scavenging and the ability to increase the cellular content of glutathion (GSH) [34, 51];

- ability to regulate membrane permeability and to increase membrane stability in the presence of xenobiotic damage [50];

- capacity to regulate nuclear expression by means of a steroid-like effect (attributed to a structural similarity of silymarin to steroid hormones) followed by tissue regeneration [52, 53];

- inhibition of the transformation of quiescent hepatic stellate cells into activated myofibroblasts which are responsible for the deposition of collagen fibres leading to cirrhosis $[54,55]$;

- anti-inflammatory effect resulting in a decrease of hepatic inflammation and inflammatory cytokines, possibly as a result of reduced tissue damage [56].

It is well known that low levels of reactive oxygen species (ROS) are actively involved in the regulation of signal transduction pathways as essential intracellular second messenger for certain cytokines and growth factor receptors, as well as of the insulin signal transduction [57]. Moreover, under pathological conditions, an excess of ROS induces apoptosis or necrosis by activating mitogen-activated protein kinases (MAPK) and caspase cascades [58].

Of the multitude of pharmacological effects attributed to silymarin in recent years, most can be explained as downstream or upstream effects of these five properties, particularly the antioxidative effects. In Fig. 1 some of these numerous effects are plotted by effective doses or concentrations, an approach already proposed by other authors [59]. This shows 


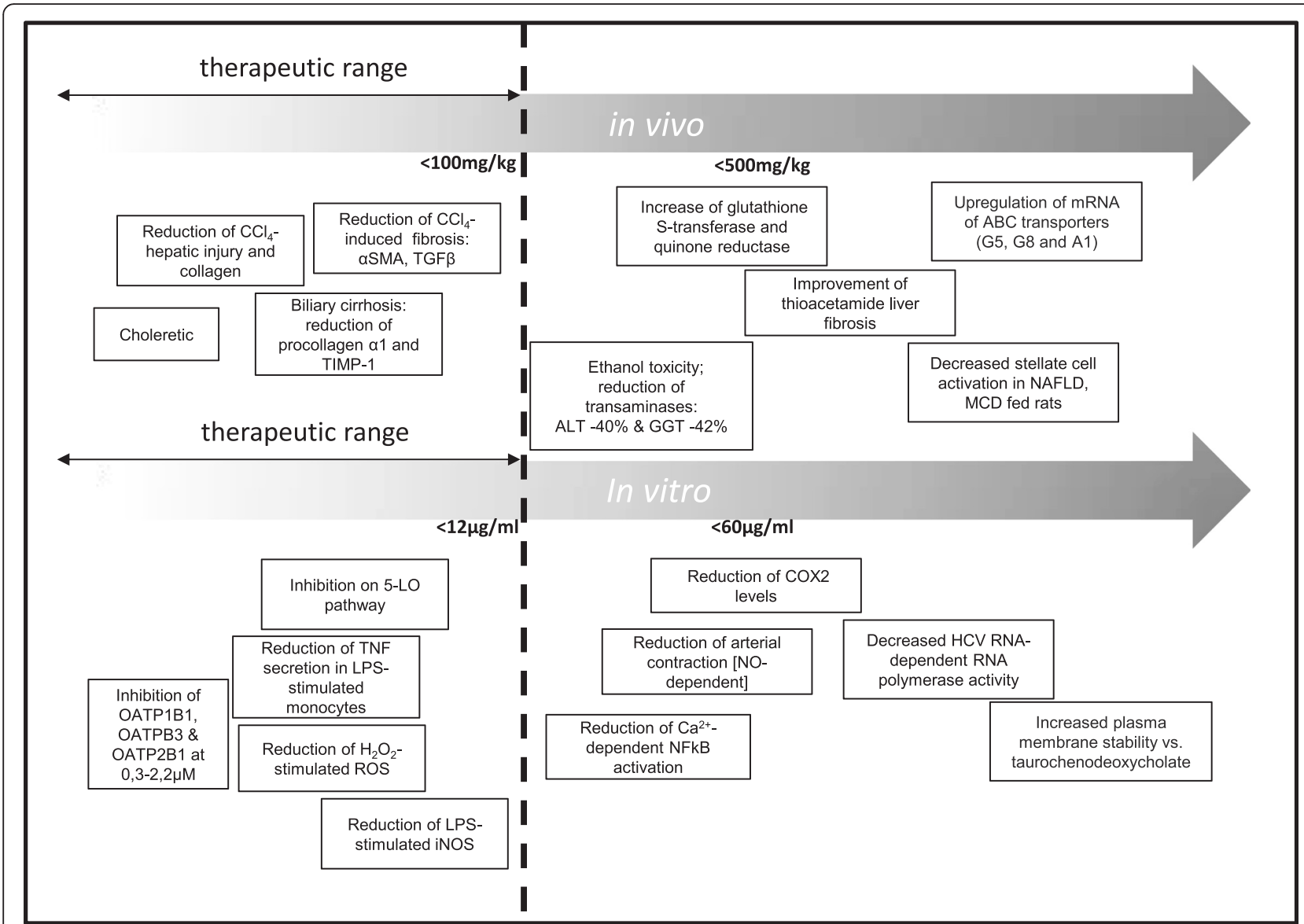

Fig. 1 Main hepatic effects of silymarin in vivo and in vitro and by doses/concentrations. The figure displays an overview on dose- or concentration-dependent effects of silymarin. For in vivo data the dotted line marks the threshold of doses above the therapeutic range in mice and humans [130]. The threshold used for the evaluation of in vitro effects of silymarin observed at concentrations representative for the therapeutic range in vivo was calculated according to the possible $C_{\max }$ after a single oral dose of 600 mg silymarin as referred to in Wen Z., et al. [29]. The threshold used for representative in vitro data corresponded to approximately 34 times the near peak plasma levels after a single human dose of $600 \mathrm{mg}$ silymarin. For references see Additional file 2

that the effects within the therapeutic range are probably mostly related to antioxidative and membrane (OATP)-related properties (Additional file 2).

\section{Clinical and specific pharmacological data \\ Alcoholic liver disease}

Excessive consumption of alcohol causes liver damage via different mechanisms including oxidative stress, hypoxia, upregulation of pro-inflammatory cytokines, and metabolic effects involving various liver cell types. Activated Kupffer cells release a variety of potentially damaging substances including cytokines, reactive oxygen species (ROS) and reactive nitrogen species (RNS) that negatively affect hepatocytes and may lead to the activation of hepatic stellate cells $[60,61]$. The response in hepatocytes includes mitochondrial damage (increase of mitochondrial AST), relative hepatic ATP depletion and altered nitric oxide (NO)-dependent control of respiration. An acceleration and propagation of these processes leads to increased hepatic inflammation, cirrhosis and HCC.

\section{Animal models}

There are many similarities between hepatotoxic agents used in animal models and the effects of chronic alcoholism. Classical animal models employ carbon tetrachloride $\left(\mathrm{CCl}_{4}\right)$ as hepatotoxic agents [62]. $\mathrm{CCl}_{4}$ is mainly activated by cytochrome P450 CYP 2E1 to form the trichloromethyl peroxyl radical which initiates lipid peroxidation of polyunsaturated fatty acids. In humans, the microsomal ethanol oxidizing system (MEOS) - induced in individuals who chronically consume alcohol also involves the cytochrome P450 CYP2E1 [63, 64]. Similar to ethanol intoxication, $\mathrm{CCl}_{4}$ progressively degrades lipids in highly reactive small molecules such as malondialdehyde (MDA) which end up inactivating the calcium pump leading to calcium influx into hepatocytes $[65,66]$. All these alterations eventually lead to liver cell 
death accompanied by the release of intrahepatic enzymes into the blood. Results from animal models applying $\mathrm{CCl}_{4}$ as well as other hepatotoxic agents, e.g. paracetamol, show a significant change in hepatic acute phase enzymes and pro-fibrotic markers due to silymarin application (Table 2) $[67,68]$. In a further experiment in rats, using $\mathrm{CCl}_{4}$ as the offending agent, a dose of $50 \mathrm{mg} /$ $\mathrm{kg}$ of silymarin was found to be more effective than $200 \mathrm{mg} / \mathrm{kg}$ in reducing oxidative stress, lysis of hepatocytes, activation of Kupffer cells, and the expression of alpha smooth muscle actin ( $\alpha$-SMA) and transforming growth factor beta 1 (TGF- $\beta 1$ ) [54]. These results confirm the hepatoprotective effect of silymarin in acute intoxication. As shown in Fig. 1 silymarin inhibits several of these steps at relatively low concentrations.

\section{Clinical data}

Despite of these potentially interesting experimental data no recent clinical studies on the role of silymarin in alcoholic hepatopathies (excluding cirrhosis) are available. Older trials which have been reviewed previously [69] showed improvement in clinical parameters associated with alcoholic liver disease (Table 3).

In 1981, Di Mario and coworkers performed a randomized, placebo controlled clinical trial over two month. 43 patients with alcohol-induced liver disease were treated with $420 \mathrm{mg}$ silymarin per day (Table 3). The results showed statistically significant reduction in alanine transaminase (ALT), aspartate transaminase (AST), bilirubin, and prothrombin in the blood. Furthermore, clinical symptoms like weakness, anorexia, and nausea improved under silymarin treatment [70]. The same doses of silymarin were applied in a trial with 97 patients by Salmi and Sama in 1982 over a period of one month. The clinical trial was performed as a randomized, double blinded versus placebo controlled study. Patients with acute or subacute alcoholic liver disease treated with milk thistle extract showed decreased liver transaminase levels compared to the non-treated group [71].

Two other clinical trials also evaluated the effect on patients with alcoholic liver disease. Feher and coworkers included 36 patients who were treated with

Table 2 Summary of dose-dependent effects of silymarin on serum markers and on tissue biochemical variables in rats (derived data as highest percent change $[67,68]$ )

\begin{tabular}{lllll}
\hline & ALT & AST & ALP & Bilirubin \\
Paracetamol & $-48 \%$ & $-80 \%$ & $-39 \%$ & $-62 \%$ \\
CCl4 & $-45 \%$ & $-46 \%$ & $-47 \%$ & $-31 \%$ \\
& TBARS & GSH & Nitrite/Nitrate & Na + K+ ATPase \\
Paracetamol & $-70 \%$ & $+100 \%$ & $-33 \%$ & $+123 \%$ \\
CCl4 & $-50 \%$ & $+164 \%$ & $-28 \%$ & $+158 \%$ \\
\hline
\end{tabular}

$140 \mathrm{mg}$ Silymarin three times a day [72]. In this study ALT and AST levels normalized. $\gamma$-GT and pro-collagen levels decreased in the silymarin group. Clinically, an improvement in liver function was detectable. A further study which included 12 patients treated with $420 \mathrm{mg}$ milk thistle extract per day for six month focused predominantly on antioxidative effects of silymarin, i.e. expression of superoxide dismutase in macrophages and erythrocytes [73]. However, the observed effects failed to reveal significance [73].

All trials did not show dramatic changes but confirmed milk thistle preparations as safe medication in patients with alcoholic liver disease. Therefore, new and larger trails over prolonged periods of time may answer the still open questions and may establish milk thistle as one therapeutic option for the treatment of alcoholic liver disease.

\section{Non-alcoholic fatty liver disease}

The diagnosis of non-alcoholic fatty liver disease (NAFLD) requires the evidence of hepatic steatosis (by imaging or histology) and the exclusion of other causes of liver disease causing steatosis. NAFLD is usually asymptomatic, so diagnosis in most cases follows the incidental finding of abnormal liver enzymes in the laboratory or steatosis on imaging. If abnormal liver function tests are present, they show only mildly raised transaminases (ALT > AST) and/or $\gamma$-GT. However, it has been claimed that up to $80 \%$ of patients have normal-range ALT levels [74, 75]. With progression of NAFLD to NASH patients often exhibit metabolic alterations including decreased insulin sensitivity, hyperlipidemia and hyperglycemia [75, 76]. Histological evaluation remains the sole method of distinguishing steatosis from advanced forms of NAFLD, i.e. non-alcoholic steatohepatitis (NASH) and for the evaluation of hepatic fibrosis [77]. Moreover, it has been reported that NAFLD/NASH may progress to hepatocellular carcinoma (HCC) also in the absence of apparent cirrhosis [77, 78].

Data generated in both, animal models and human studies provide growing evidence that the progression of NAFLD is also related to an altered intestinal microbiome and an impairment of the gut's physical, chemical and immunological barrier functions [79, 80]. Among others changes in the enteric microbiome and an increased intestinal permeability contribute to an overflow of bacterial metabolites into the liver via the portal vein driving the progression of NAFLD. Among the metabolites of the intestinal microbiome are short-chain fatty acids, major gut microbial fermentation products, and ethanol. While short-chain fatty acids enhance intestinal absorption by activating glucagon-like peptide-2, ethanol causes triglyceride accumulation in hepatocytes via production of reactive oxygen species and initiation of liver 
Table 3 Clinical trials applying silymarin to patients with alcoholic liver disease

\begin{tabular}{|c|c|c|c|c|c|c|}
\hline \multirow[t]{2}{*}{ Study } & \multicolumn{2}{|c|}{ Silymarin } & \multicolumn{2}{|c|}{ Control } & \multirow{2}{*}{$\begin{array}{l}\text { Weight }{ }^{a} \\
\%\end{array}$} & \multirow{2}{*}{$\begin{array}{l}\text { WMD (fixed) } \\
95 \% \mathrm{Cl}\end{array}$} \\
\hline & $\mathrm{N}$ & Mean (SD) & $\mathrm{N}$ & Mean (SD) & & \\
\hline DiMario et al., 1981 [70] & 15 & $25.40(15.60)$ & 14 & $50.60(24.30)$ & 3.38 & $-25.20[-40.18,-10.22]$ \\
\hline Salmi et al., 1982 [71] & 47 & $38.20(15.99)$ & 50 & $51.20(24.99)$ & 11 & $-13.00[-21.30,-4.70]$ \\
\hline Feher et al., 1989 [72] & 17 & $22.80(5.10)$ & 19 & $31.30(4.50)$ & 76.01 & $-8.50[-11.66,-5.34]$ \\
\hline Müzes et al., 1990 [73] & 10 & $28.00(11.00)$ & 20 & $52.00(13.00)$ & 9.6 & $-24.00[-32.88,-15.12]$ \\
\hline Total (95 \% Cl) & 89 & & 103 & & 100 & $-11.05[-13.80,-8.29]$ \\
\hline
\end{tabular}

${ }^{a}$ Weighted mean differences of aspartate aminotransferase (AST) serum levels comparing control patients and patients receiving silymarin after the end of treatment

Test for heterogeneity: $\mathrm{Chi}^{2}=14.31, \mathrm{df}=3(P=0.003), \mathrm{I}^{2}=79.0 \%$

Test for overall effect: $Z=7.86(P<0.00001)$

inflammation. This might provide a second hit to the liver that had already accumulated fat [81-83]. Furthermore, the gut-derived bacterial products stimulate innate immune receptors, namely Toll-like receptors (TLRs), expressed on most hepatic cells, thus contributing to acute and chronic liver diseases via immune activation, i.e. cytokine production [84]. In a kind of circulus vitiosus, the inflammatory changes in the liver seem to contribute to an increased intestinal permeability [85]. While metabolic adaptations occur to compensate for the increased liver fat load, mitochondria eventually become dysfunctional with increased generation of reactive oxygen species and impaired electron transport chain activity; both of which contribute to insulin resistance [86].

There are no silymarin specific data concerning its intestinal effects in NAFLD/NASH in animal experiments or patients. However, several reports indicated different effects on the intestine which are worthwhile mentioning. Thus, silymarin applied in clinically relevant doses has been shown to have protective effects against trinitrobenzene sulphonic acid (TNBS)-induced colitis in rats [87], inhibition of epirubicin-induced gastrointestinal mucositis in mice [88] and reduction of oxidative and intestinal damage induced by ischemia-reperfusion injuries in rats [89]. It was also found to be effective against cold-restraint stress induced gastric ulcers in rats at a dose of $50 \mathrm{mg} / \mathrm{kg}$ per os [90].

In patients with ulcerative colitis in remission, $92 \%$ of the patients in the silymarin group remained in complete remission with no flare-up after 6 months as compared to $66 \%$ in the placebo group $(P<0.01)$ [91]. Moreover, in hemochromatosis patients, homozygous for the C282Y mutation in the HFE-associated gene, silibinin at a dose of $140 \mathrm{mg}$ inhibited the iron absorption by $43 \%[91,92]$.

\section{Animal models}

Hepatoprotective effects of silymarin have been reported in different animal models of NAFLD/NASH [93]. In one model, Otsuka Long-Evans Tokishima Fatty (OLETF) rats were fed with a methionine-and choline-deficient (MCD) diet [56, 94]. In this model a diet mixed with silymarin $0.5 \%$ w/w (approx. $390 \mathrm{mg} / \mathrm{kg}$.day) caused a modest but significant improvement of the NAFLD activity score within 8 weeks, reduced histological signs of fibrosis and expression of profibrigenic factors [56, 95]. Favorable results with a silymarin formulation were reported in mice suffering from a streptozotocin plus high-fat diet induced NASH. Steatosis score improved but the daily milk thistle doses of 500 and $1000 \mathrm{mg} / \mathrm{kg}$ are hardly predictive of a clinical setting [96]. Indirect confirmation came from similar studies conducted with four weeks silibinin (20 mg/kg i.p.) in $\mathrm{db} / \mathrm{db}$ mice [95]. A further similar protocol showed that silibinin decreased insulin resistance in the HOMA-IR test, serum ALT and markedly improved hepatic and myocardial damage [97]. Silibinin reduced isoprostanes, 8-deoxyguanosine and nitrites/nitrates and restored glutathione levels in the liver.

\section{Clinical data}

Patients suffering from NAFLD/NASH are hard to find because of the symptoms like diabetes, insulin resistance and /or obesity do not directly link to NAFLD/NASH. Several groups have been interested in examining the potential of silymarin in the treatment of NAFLD/ $\mathrm{NASH}$. In three comparative trials silymarin has been tested against placebo, in one against vitamin $\mathrm{E}$, and in one against pioglitazone and metformin (Summary in Table 4, [98-102]). Furthermore, three Italian groups conducted open trials applying silymarin combined with other agents (see Additional file 3). The main interest of latter lies in the criteria used to assess evolution in clinical parameters; e.g. ultrasonographic score, the SteatoTest, the Hepatic Steatosis Index (HSI) and the Lipid Accumulation Product (LAP) index.

Hajani and coworkers compared the effect of vitamin E $400 \mathrm{IU} / \mathrm{d}$ to patients receiving silymarin $70 \mathrm{mg}$ for three times a day over a period of 12 weeks [98]. AST/ ALT levels served as diagnostic parameters. The authors concluded a potential for both substances to lower AST/ ALT levels. Two other placebo controlled trials used 
Table 4 Clinical trials with silymarin vs. placebo or other drugs in NAFLD/NASH

\begin{tabular}{|c|c|c|c|c|c|}
\hline Author & Hajiani et al. 2009 [98] & Hashemi et al. 2009 [100] & $\begin{array}{l}\text { Hajiaghamo-hammadi } \\
\text { et al. } 2012 \text { [102] }\end{array}$ & Masoodi, et al. 2013 [99] & Solhi et al. 2014 [101] \\
\hline Diagnosis & $\begin{array}{l}\text { abdominal sonography } \\
\text { at entry \& at the end } \\
\text { (NAFLD) }\end{array}$ & $\begin{array}{l}\text { abdominal sonography or } \\
\text { liver biopsy (NAFLD or } \\
\text { NASH) }\end{array}$ & $\begin{array}{l}\text { abdominal sonography } \\
\text { + increased AST/ALT } \\
\text { serum levels }\end{array}$ & $\begin{array}{l}\text { abdominal sonography + } \\
\text { increased AST/ALT serum } \\
\text { levels (NASH) }\end{array}$ & $\begin{array}{l}\text { abdominal sonography } \\
+ \text { increased AST/ALT } \\
\text { serum levels }\end{array}$ \\
\hline Type of Trial & $\begin{array}{l}\text { Open label, } \\
\text { Comparative }\end{array}$ & Comparative randomized & $\begin{array}{l}\text { Comparative } \\
\text { randomized }\end{array}$ & Comparative, double blind & $\begin{array}{l}\text { Comparative } \\
\text { randomized }\end{array}$ \\
\hline $\begin{array}{l}\text { Duration of } \\
\text { silymarin } \\
\text { application }\end{array}$ & 12 weeks & 24 weeks & 8 weeks & 12 weeks & 8 weeks \\
\hline Silymarin dose & $70 \mathrm{mg}$ tid & $140 \mathrm{mg}$ bid & 140 mg/d [S] & $140 \mathrm{mg}$ bid & 70 mg tid \\
\hline Comparator & $\begin{array}{l}\text { vitamin E } 400 \mathrm{IU} \text { d/12 } \\
\text { w. }\end{array}$ & Placebo & $\begin{array}{l}\text { pioglitazone } 15 \mathrm{mg} / \mathrm{d} \\
\text { [P], metformin } 500 \mathrm{mg} / \\
\mathrm{d}[\mathrm{M}]\end{array}$ & Placebo & Placebo \\
\hline N pts./Group & $71 / 71$ & $50 / 50$ & S 22 / P 22 / M 22 & $50 / 50$ & $33 / 31$ \\
\hline \multirow[t]{2}{*}{$\begin{array}{l}\text { Outcomes } \\
\text { (Significances } \\
\text { End of TT) }\end{array}$} & $\begin{array}{l}\text { AST Normal. } 74.6 \% \text { vs. } \\
56.3 \% \text { pts }(P=0.025)\end{array}$ & $\begin{array}{l}\text { AST }<40 \text { in } 62 \% \text { of cases } \\
\text { Silymarin vs } 20 \% \text { placebo } \\
(P<0.001) .\end{array}$ & $\begin{array}{l}\text { AST Normal. S } 62 \% \text {, P } \\
68 \%, M 54 \%(P<0.1)\end{array}$ & $\begin{array}{l}\text { Mean AST } 54.7 \text { UI vs. 61.6; } \\
(P<0.2 ; \text { CAVE diff. At } \\
\text { admission })\end{array}$ & $\begin{array}{l}\text { Mean AST } 30 \text { UI vs. } 36 \\
\text { UI; }(P=0.04)\end{array}$ \\
\hline & $\begin{array}{l}\text { ALT Normal. } 41 \% \text { vs. } \\
45 \% \text { pts (N.S.) }\end{array}$ & $\begin{array}{l}\text { ALT }<56 \text { in } 52 \% \text { of cases } \\
\text { Silymarin vs } 18 \% \text { placebo } \\
(P<0.001)\end{array}$ & $\begin{array}{l}\text { ALT Normal. S } 18 \% \text {, } P \\
27 \%, M 9 \%(P>0.1)\end{array}$ & $\begin{array}{l}\text { Mean ALT } 68.54 \text { UI vs. } \\
73.3 ;(P<0.5 . \text {., CAVE diff. at } \\
\text { admission) }\end{array}$ & $\begin{array}{l}\text { Mean ALT } 38 \text { UI vs. } 52 \\
\text { UI }(P=0.03)\end{array}$ \\
\hline End-Points $^{\mathrm{a}}$ & Not Reported & Not Reported ${ }^{\text {b }}$ & Not Reported ${ }^{c}$ & Not Reported & Not Reported \\
\hline $\begin{array}{l}\text { Quality } \\
\text { (Simplified } \\
\text { Consort } \\
\text { Checklist) }\end{array}$ & $5 / 10$ & $4 / 10$ & $4 / 10$ & $4 / 10$ & $5 / 10$ \\
\hline
\end{tabular}

AST/ALT levels and abdominal sonography to evaluate the effect of silymarin in NAFLD. Although the number of participants, doses and period of treatment were different, both trials revealed a tendency to reduce ALT/ AST levels in silymarin treated patients [99, 101]. In comparison to pioglitazone and metformin, silymarin also caused a more significant change in ALT/AST levels [102]. However, the effect of silymarin on triglycerides, fasting blood sugar, and insulin levels was rather weak compared to pioglitazone treatment [102]. Thus, the effect of silymarin on insulin and other metabolic parameters in the liver is an open question.

The quality of the scientific reporting in these studies was limited. However, one may extract some relevant information: among the placebo controlled trials we may retain two $[100,101]$ that showed significant differences in favor of silymarin in the ALT and AST levels at the end of the trials.

The data provide a rational for silymarin as a comedication in NAFLD/NASH. Due to its positive effects on liver integrity silymarin might also improve the effect of other therapies. For follow up clinical trials, one has to keep in mind that the dosage of silymarin per day and the observation period have to be taken under special consideration. Referring to the pharmacokinetics of silymarin the plasma levels in these studies might have been too low to reach optimal therapeutic concentrations. Nevertheless, the existing evidence merits further studies with appropriate scientific standard.

\section{Hepatic fibrosis and cirrhosis}

In response to acute liver injury fibrosis arises as part of an attempted wound-healing response that aims to maintain organ structure and integrity [16]. However, in chronic liver injury prolonged fibrosis leads to a progressive tissue scaring process ending up in remodeling of the liver tissue structure. Ultimately, hepatic fibrosis can lead to liver cirrhosis and end stage liver disease. Moreover, cirrhosis is the major risk factor for HCC. A recent assessment of liver cirrhosis mortality led to a global estimate of just over one million deaths in 2010 which was approximately $2 \%$ of all deaths $[3,103]$.

The pathophysiology of hepatic fibrosis involves the generation of reactive oxygen species (ROS). Cytochrome P450 2E1 is the main source of ROS in hepatocytes [104]. Activated hepatic stellate cells, portal fibroblasts, and myofibroblasts of bone marrow origin have been identified as major collagen-producing cells in the injured liver. These cells are activated by redoxsensitive intracellular pathways and fibrogenic cytokines 
such as TGF- $\beta 1$, angiotensin II, and leptin. Reversibility of advanced liver fibrosis in patients has been documented which has stimulated researchers to develop antifibrotic drugs. However, prolonged liver injury will cause irreversible crosslinking of extracellular matrix leading to uncleavable collagen fibers. Antioxidants may inhibit hepatic stellate cells (HSCs) activation, protecting hepatocytes and attenuating experimental liver fibrosis [105-107].

\section{Experimental pharmacology}

Animal models only incompletely recapitulate the complexity of human liver disorders. Limiting factors are the differences in time frames to develop a given pathology, differences immune systems and differences in metabolic rates [108]. However, experimental models can give important insights into the antifibrotic mechanisms of action of a specific compound. In recent years there have been several experimental publications describing an antifibrotic activity of silymarin upon oral application although, frequently, at doses above the therapeutic range. Some of them are listed in Table 5 [109-113].

\section{Clinical data}

There have been no modern clinical trials conducted in alcoholic cirrhosis; the trials dealing with this indication have been described in extenso in other publications.

It seems worthwhile recalling that in the older alcoholic cirrhosis trials reporting on mortality and liverrelated mortality (Table 6) there was a non-significant reduction of overall mortality ( $16.1 \%$ vs. $20.6 \%$ ) with an odds ratio of 0.69 [95\% CI, $0.45,1.07]$, but a significant reduction of liver-related mortality (10.6\% vs. $17.6 \%)$ with an odds ratio of 0.52 [95\% CI, 0.32, 0.84]. Liverrelated mortality comprised hepatic failure and complications of portal hypertension such esophageal varices, liver abscess, malignant neoplasm of liver and of intrahepatic bile duct [114]. In two trials the total incidence of upper gastrointestinal bleedings showed a difference in favor of the active silymarin treatment (4.6 with silymarin vs. 9.6 with placebo and $6.3 \%$ vs. $13.5 \%$ respectively, $P=0.042$ ). Hepatic cancer has not been investigated systematically in any of these trials, but in two of them it has been reported as cause of death, and/ or found at biopsy or at autopsy (silymarin $=3.1 \%$, placebo $=4.5 \%$, and silymarin $=3.4 \%$, placebo $=7.1 \%$, respectively) $[115,116]$.

Similar conclusions concerning mortality were drawn in an exhaustive meta-analysis of the clinical trials with silymarin, including this indication, published some years ago by the Cochrane group [117].

\section{Other liver injuries \\ Intoxication with Amanita phalloides}

Intravenous silibinin continues to be part of the standard treatment in case of intoxication with $A$. phalloides [118]. However, the clinical efficacy of any modality of treatment is difficult to demonstrate since randomized, controlled clinical trials have not been reported. The clinical evidence supporting the use of i.v. silibinin in case of intoxication with $A$. phalloides has been reviewed [119]. One further publication reported on silymarin application to a series of 10 Australian patients with probable poisoning and two patients with possible poisoning, respectively. Despite treatment according to the standard regime with i.v. silibinin mortality rate was still high [120]. Furthermore, two cases of successfully treated intoxications with $A$. ocreata have been reported from the Northeastern USA [121].

\section{Neonatal jaundice}

Silymarin has also been applied in the context of the management of hyperbilirubinemia in neonatal jaundice. In a comparative study with 170 neonates the mean duration of phototherapy was found to be significantly reduced from $5.3 \pm 0.82$ days in the control group to $4.2 \pm 0.76(p=0.001)$ days in the silymarintreated group ( $3.75 \mathrm{mg} / \mathrm{kg}$ of silymarin twice daily); increased ALT and AST serum levels were also improved in the silymarin-treated group $(p=0.001)$ [122].

\section{Use as adjunctive to in chemotherapy}

In a study reported in 2010, 50 children with acute lymphocytic leukemia (ALL) were enrolled in a randomized study testing placebo vs. silymarin for treatment of

Table 5 Experimental models for anti-fibrotic effects of Silybum marianum

\begin{tabular}{lll}
\hline Model & Silymarin doses & Effect \\
\hline $\begin{array}{l}\text { CCl4 in transgenic } \\
\text { mice }\end{array}$ & $200 \mathrm{mg} / \mathrm{kg}$ & Ex vivo reduction of the genes Cox6a2, 7a1, Cox8b [113] \\
CCl4 & $50 \mathrm{mg} / \mathrm{kg}$ & Anti-inflammatory effect, HSC activation, mast cell stabilization, TGF $\beta$ secretion[109] \\
Thioacetamid & $150 \mathrm{mg} / \mathrm{kg}$ & Body weight $\downarrow$, serum cholesterol $\downarrow$, TG $\downarrow$, liver size $\uparrow$, ALT/AST $\downarrow$,[1 10] \\
CCl4 & $100 \mathrm{mg} / \mathrm{kg}$ i.p. (non therapeutic & $\begin{array}{l}\text { Reduction of hepatic collagen content 18\%, Reduction hepatic fibrosis score 47 \% } \\
{[111]}\end{array}$ \\
route) & Reduction of inflammatory and fibrotic effects [131] \\
\hline
\end{tabular}


Table 6 Mortality as relative risk (RR) in placebo controlled cirrhosis trials

\begin{tabular}{|c|c|c|c|c|c|c|c|c|}
\hline \multirow[t]{3}{*}{ Study } & \multirow{3}{*}{$\begin{array}{l}\text { Duration } \\
\text { (Mo.) }\end{array}$} & \multirow{3}{*}{$\begin{array}{l}\text { Dose } \\
\text { mg/day }\end{array}$} & \multirow{3}{*}{$\begin{array}{l}\text { Silymarin } \\
\text { (nt) nL/N }\end{array}$} & \multirow{3}{*}{$\begin{array}{l}\text { Control } \\
\text { (nt) } \mathrm{nL} / \mathrm{N}\end{array}$} & \multicolumn{2}{|c|}{ (Total mortality) } & \multicolumn{2}{|c|}{ Liver Related Mortality } \\
\hline & & & & & (Weight) & (RR (fixed)) & Weight & RR (fixed) \\
\hline & & & & & (\%) & $(95 \% \mathrm{Cl})$ & $\%$ & $95 \% \mathrm{Cl}$ \\
\hline Ferenci, 1989 [115] & 24 & 420 & (28) $18 / 87$ & (39) $31 / 83$ & $(61.79)$ & $(0.68[0.47,1.00])$ & 57.29 & $0.55[0.34,0.91]$ \\
\hline Trinchet,1989 [132] & 3 & 420 & (1) $01 / 57$ & (3) $03 / 59$ & $(4.56)$ & $(0.35[0.04,3.22])$ & 5.32 & $0.35[0.04,3.22]$ \\
\hline Bunout,1992 [133] & 15 & 280 & (5) $04 / 34$ & (5) $05 / 37$ & $(7.41)$ & $(1.09[0.34,3.43])$ & 8.65 & $0.87[0.25,2.98]$ \\
\hline Pares,1998 [116] & 24 & 450 & (16) $10 / 103$ & (15) $14 / 97$ & (23.91) & $(1.00[0.53,1.92])$ & 26.04 & $0.67[0.31,1.44]$ \\
\hline Lucena, 2002 [134] & 6 & 450 & (0) $0 / 30$ & (1) $1 / 30$ & $(2.32)$ & $(0.33[0.01,7.87])$ & 2.71 & $0.33[0.01,7.87]$ \\
\hline Total (95 \% Cl) & & & (50) $33 / 311$ & (63) $54 / 306$ & (100) & $(0.77[0.56,1.05])$ & 100 & $0.60[0.40,0.88]$ \\
\hline
\end{tabular}

Total mortality: Test for heterogeneity: $\mathrm{Chi}^{2}=2.12, \mathrm{df}=4(P=0.71), \mathrm{I}^{2}=0 \%$; Test for overall effect: $\mathrm{Z}=1.65(P=0.10)$. Liver Related Mortality: Test for heterogeneity: $\mathrm{Chi}^{2}=0.90, \mathrm{df}=4(P=0.92), \mathrm{I}^{2}=0 \%$; Test for overall effect: $\mathrm{Z}=2.64(P=0.008)$

chemotherapy-associated hepatotoxicity [123]. No significant differences in the frequency of side effects or infections were observed between groups. With regard to the degree of liver damage there was no significant change in AST, ALT, or total bilirubin levels on day 28. However, on day 56 , the milk thistle group $(5.1 \mathrm{mg} / \mathrm{kg} /$ day) had significantly lower AST serum levels $(p=0.04)$. In addition, a retrospective analysis of patients with post chemotherapy mild temporary hepatic failure (PCMTHF) showed a faster recovery under silymarin treatment compared to those under standard management [124].

\section{Iron overload}

Genetic or transfusion-associated iron overload is a common cause of chronic liver injury, fibrosis or even cirrhosis. As standard treatments depletion of iron stores by phlebotomy and in some cases application of iron chelators are considered. Earlier studies observed an additional, positive effect (e.g. reduced serum iron and serum ferritin in 3 out of 4 trials) for silymarin [125, 126]. In addition, the role of silymarin in a combined regimen with deferasirox or deferiprone in the treatment of the iron overload in Beta-Thalassemia is currently under investigation in several clinical trials.

\section{Conclusion}

Chronic toxicity studies in rodents have confirmed that silymarin has a very low toxicity, and at very high doses it rather reduced than increased the incidence of some spontaneous neoplasias in rodents. These data strongly support the large therapeutic index of silymarin and bolster its history of safe medication.

Pharmacokinetic studies showed that (i) the type of hepatic pathology has a major impact on the kinetics of silymarin, (ii) doses above $700 \mathrm{mg}$ tid may reach much higher blood levels than predicted from linear dose/blood levels at lower doses and (iii) the short half-life of silymarin indicates that at least 3 daily intakes are needed to warrant sustained effective blood levels. No clinically relevant interactions between silymarin and other drugs have been identified so far.

Of the multitude of pharmacological effects attributed to silymarin in recent years, most can be attributed to its antioxidative and membrane-stabilizing properties. Available clinical studies related to the application of silymarin in toxic hepatological disorders have limitations. Still, the favorable risk/benefit ratio justifies continuing the use of silymarin in these indications. Nevertheless, further studies addressing the optimization of dosing schedules, pharmaceutical drug formulations, and patient selection are needed.

In spite of promising experimental data there have been no recent clinical studies in alcoholic liver disease (excluding cirrhosis). However, older trials reported reduced AST serum levels in response to silymarin treatment. It seems worthwhile recalling that in alcoholic cirrhosis trials there was no significant reduction of overall mortality and of liver-related mortality.

In the rapidly evolving indication NAFLD/NASH, animal and human studies show that silymarin may reach higher blood levels compared to healthy controls. Furthermore, it may have beneficial effects on the intestine in addition to liver-protecting effects. Several comparative trials have shown some benefits referring to AST and ALT levels in NAFLD / NASH patients. However, most of these studies had methodological limitations.

Quo vadis silymarin? As pointed out, further clinical studies of higher scientific quality analyzing long term application and clinical outcomes are needed to support evidence for the use of silymarin in different types of chronic liver disease. These studies also need to pay increased attention to nutritional and life-style covariates like smoking [127], coffee consumption [128], physical activity [129] particularly, in the context of NAFLD. Furthermore, available experimental and clinical studies 
teach us that future clinical trials should focus on longterm observations because with silymarin's effects are unlikely to be acute and dramatic but rather progressive over time.

\section{Additional files}

Additional file 1: Search strategy. (DOCX $55 \mathrm{~kb}$ )

Additional file 2: Overview of publications listed in Pubmed on silimarin, silibinin, or milk thistle. (DOCX $82 \mathrm{~kb}$ )

Additional file 3: Silymarin preparations in open NAFLD / NASH trials. (DOCX $22 \mathrm{~kb}$ )

\section{Abbreviations}

ALT: alanine aminotransferase; AST: aspartate aminotransferase; AUC: area under the curve; $\mathrm{CCl}_{4}$ : carbon tetrachloride; $\mathrm{C}_{\text {max }}$ : maximum (or peak) serum concentration; CTGF: connective tissue growth factor; CYP: cytochrome; GSH: glutathion; HCC: hepatocellular carcinoma; HFE: human hemochromatosis protein; HMPC: Committee on Herbal Medicinal Products; HSC: hepatic stellate cell; IFN: interferon; IL-6: interleukin-6; iNOS: inducible nitric oxide synthase; IR: insulin resistance; MRP: multidrug Resistance Associated Proteins; NAFLD: non-alcoholic fatty liver disease; NASH: nonalcoholic steatohepatitis; NFkB: nuclear factor kappa-light-chain-enhancer of activated B cells; OATP: organic anion-transporting polypeptides; ROS: reactive oxygen substances; TBARS: thiobarbituric acid reactive substances; TGF $\beta 1$ : transforming growth factor beta-1; tid: three times a day; TLR: toll-like receptors; TNFa: tumour necrosis factor alpha; UDCA: ursodeoxycholic acid; a-SMA: a-smooth muscle actin (fibroblast contractility); $\gamma$-GT: gamma-glutamyltransferase.

\section{Competing interests}

This work has been supported by a grant from Bionorica SE, Germany. Philipp Peterburs and Anja Lechner are employees of Bionorica SE. The authors state that they hold neither equities nor any other financial interest in this company. Claus Hellerbrand is working as a scientific advisor for Bionorica SE and part of projects related to phyto-extracts from the lab of Claus Hellerbrand are funded by Bionorica SE. Claus Hellerbrand, Jörn M. Schattenberg, Philipp Peterburs, Anja Lechner and Reto Brignoli declare that they have no further competing interests.

\section{Authors' contributions}

$\mathrm{RB}$ conceptualized and wrote the first draft of the manuscript, in addition to revising and finalizing the corrected article proofs. PP \& AL revised and edited the draft of the manuscript, tables and graphs. CH \& JS contributed to critical reading of the manuscript and final editing of the revised manuscript. All authors read and approved the final manuscript.

\section{Acknowledgements}

The authors thank Dr. Aldo Ammendola, Dimitri Abramov-Sommariva MD and Eugen Baumgaertner MD for critical discussions during the writing and reviewing process.

\section{Author details}

${ }^{1}$ Department of Internal Medicine I, University Hospital Regensburg, Franz-Josef-Strauss-Allee 11, 93053 Regensburg, Germany. ${ }^{2}$. Department of Medicine, University Medical Center Mainz, Langenbeckstrasse 1, 55131 Mainz, Germany. ${ }^{3}$ Bionorica SE, Kerschensteinerstraße 11-15, 92318 Neumarkt, Germany. ${ }^{4}$ TRADYSER GmbH, Ahornweg 22, 8630 Rüti, Switzerland.

Received: 27 November 2015 Accepted: 11 February 2016 Published online: 24 February 2016

\section{References}

1. Anthony KP, Saleh MA. Free radical scavenging and antioxidant activities of silymarin components. Antioxidants. 2013;2(4):398-407.

2. Saucedo. Harmful use of Alcohol Alcohol Use Disorders and Alcoholic Liver Diseases. Priority Medicines for Europe and the World "A Public Health
Approach to Innovation"Update on 2004 Background Paper, BP 614 Alcohol Use Disorders.

3. Mokdad AA, Lopez AD, Shahraz S, Lozano R, Mokdad AH, Stanaway J, et al. Liver cirrhosis mortality in 187 countries between 1980 and 2010: a systematic analysis. BMC medicine. 2014;12:145. doi:10.1186/s12916-0140145-y.

4. Charlton MR, Burns JM, Pedersen RA, Watt KD, Heimbach JK, Dierkhising RA. Frequency and outcomes of liver transplantation for nonalcoholic steatohepatitis in the United States. Gastroenterology. 2011;141(4):1249-53. doi:10.1053/j.gastro.2011.06.061.

5. Wong RJ, Aguilar M, Cheung R, Perumpail RB, Harrison SA, Younossi ZM, et al. Nonalcoholic steatohepatitis is the second leading etiology of liver disease among adults awaiting liver transplantation in the United States. Gastroenterology. 2015;148(3):547-55. doi:10.1053/j.gastro.2014.11.039.

6. Bellentani S, Scaglioni F, Marino M, Bedogni G. Epidemiology of nonalcoholic fatty liver disease. Digestive diseases (Basel, Switzerland). 2010; 28(1):155-61. doi:10.1159/000282080.

7. Blachier M, Leleu H, Peck-Radosavljevic M, Valla DC, Roudot-Thoraval F. The burden of liver disease in Europe: a review of available epidemiological data. J Hepatol. 2013;58(3):593-608. doi:10.1016/j.jhep.2012.12.005.

8. Scalone L, Fagiuoli S, Ciampichini R, Gardini I, Bruno R, Pasulo L, et al. The societal burden of chronic liver diseases: results from the COME study. BMJ open gastroenterology. 2015;2(1):e000025. doi:10.1136/bmjgast-2014000025.

9. ECDC. Hepatitis B and C in the EU neighbourhood: prevalence, burden of disease and screening policies. 2010.

10. Rehermann B, Bertoletti A. Immunological aspects of antiviral therapy of chronic hepatitis $B$ virus and hepatitis $C$ virus infections. Hepatology (Baltimore, Md). 2015;61(2):712-21. doi:10.1002/hep.27323.

11. Wagoner J, Morishima C, Graf TN, Oberlies NH, Teissier E, Pecheur El, et al. Differential in vitro effects of intravenous versus oral formulations of silibinin on the HCV life cycle and inflammation. PLoS One. 2011;6(1):e16464. doi:10. 1371/journal.pone.0016464.

12. Mayer KE, Myers RP, Lee SS. Silymarin treatment of viral hepatitis: a systematic review. J Viral Hepat. 2005;12(6):559-67. doi:10.1111/j.1365-2893. 2005.00636.x

13. Ferenci $P$, Beinhardt S. Silibinin: an old drug in the high tech era of liver transplantation. J Hepatol. 2013;58(3):409-11. doi:10.1016/j.jhep.2012.11.030.

14. Seeff LB, Curto TM, Szabo G, Everson GT, Bonkovsky HL, Dienstag JL, et al. Herbal product use by persons enrolled in the hepatitis C Antiviral LongTerm Treatment Against Cirrhosis (HALT-C) Trial. Hepatology (Baltimore, Md). 2008;47(2):605-12. doi:10.1002/hep.22044.

15. Freedman ND, Curto TM, Morishima C, Seeff LB, Goodman ZD, Wright EC, et al. Silymarin use and liver disease progression in the Hepatitis C Antiviral Long-Term Treatment against Cirrhosis trial. Aliment Pharmacol Ther. 2011; 33(1):127-37. doi:10.1111/j.1365-2036.2010.04503.x.

16. Zheng ZY, Weng SY, Yu Y. Signal molecule-mediated hepatic cell communication during liver regeneration. World J Gastroenterol. 2009; 15(46):5776-83.

17. Henao-Mejia J, Elinav E, Jin C, Hao L, Mehal WZ, Strowig T, et al. Inflammasome-mediated dysbiosis regulates progression of NAFLD and obesity. Nature. 2012;482(7384):179-85. doi:10.1038/nature10809.

18. Bajaj JS, Heuman DM, Hylemon PB, Sanyal AJ, White MB, Monteith P, et al. Altered profile of human gut microbiome is associated with cirrhosis and its complications. J Hepatol. 2014;60(5):940-7. doi:10.1016/j.jhep.2013.12.019.

19. Vargas-Mendoza N, Madrigal-Santillan E, Morales-Gonzalez A, Esquivel-Soto J, Esquivel-Chirino C, Garcia-Luna YG-RM, et al. Hepatoprotective effect of silymarin. World J Hepatol. 2014;6(3):144-9. doi:10.4254/wjh.v6.i3.144.

20. Greek R, Menache A. Systematic reviews of animal models: methodology versus epistemology. International journal of medical sciences. 2013;10(3): 206-21. doi:10.7150/ijms.5529.

21. Robb-Gaspers LD, Thomas AP. Coordination of Ca2+ signaling by intercellular propagation of Ca2+ waves in the intact liver. The Journal of biological chemistry. 1995;270(14):8102-7.

22. Schlosser SF, Burgstahler AD, Nathanson MH. Isolated rat hepatocytes can signal to other hepatocytes and bile duct cells by release of nucleotides. Proc Natl Acad Sci U S A. 1996:93(18):9948-53.

23. Ghosh AGT, Jain S. Silymarin-a review on pharmacodynamics and bioavailability enhancement. Journal of Pharmaceutical Science and Technology. 2010;2(10):348-55. 
24. Dunnick JK NA, Bishop JB, Bucher JR, Chhabra RS, Foster PM, Herbert RA, et al. Toxicology and carcinogenesis studies of milk thistle extract (CAS No. 84604-20-6) in F344/N rats and B6C3F1 mice (Feed Studies). National Toxicology Program technical report series. 2011;565:1-177.

25. Dunnick JK, Nyska A. The toxicity and pathology of selected dietary herbal medicines. Toxicol Pathol. 2013:41(2):374-86. doi:10.1177/ 0192623312466451.

26. Bunel V, Ouedraogo M, Nguyen AT, Stevigny C, Duez P. Methods applied to the in vitro primary toxicology testing of natural products: state of the art, strengths, and limits. Planta Med. 2014;80(14):1210-26. doi:10.1055/s-0033-1360273.

27. Polyak SJ, Ferenci P, Pawlotsky JM. Hepatoprotective and antiviral functions of silymarin components in hepatitis $C$ virus infection. Hepatology (Baltimore, Md). 2013;57(3):1262-71. doi:10.1002/hep.26179.

28. Tushar Kanti Maiti KSG, Samanta A, Dasgupta S. The interaction of silibinin with human serum albumin: a spectroscopic investigation. Journal of Photochemistry and Photobiology. 2008;194(2-3):297-307.

29. Wen Z, Dumas TE, Schrieber SJ, Hawke RL, Fried MW, Smith PC. Pharmacokinetics and metabolic profile of free, conjugated, and total silymarin flavonolignans in human plasma after oral administration of milk thistle extract. Drug metabolism and disposition: the biological fate of chemicals. 2008;36(1):65-72. doi:10.1124/dmd.107.017566.

30. Calani L, Brighenti F, Bruni R, Del Rio D. Absorption and metabolism of milk thistle flavanolignans in humans. Phytomedicine : international journal of phytotherapy and phytopharmacology. 2012;20(1):40-6. doi:10.1016/j. phymed.2012.09.004

31. Miranda SR, Lee JK, Brouwer KL, Wen Z, Smith PC, Hawke RL. Hepatic metabolism and biliary excretion of silymarin flavonolignans in isolated perfused rat livers: role of multidrug resistance-associated protein 2 (Abcc2). Drug metabolism and disposition: the biological fate of chemicals. 2008; 36(11):2219-26. doi:10.1124/dmd.108.021790.

32. Schrieber SJ, Wen Z, Vourvahis M, Smith PC, Fried MW, Kashuba AD, et al. The pharmacokinetics of silymarin is altered in patients with hepatitis $C$ virus and nonalcoholic Fatty liver disease and correlates with plasma caspase-3/7 activity. Drug metabolism and disposition: the biological fate of chemicals. 2008;36(9):1909-16. doi:10.1124/dmd.107.019604.

33. Hawke RL, Schrieber SJ, Soule TA, Wen Z, Smith PC, Reddy KR, et al. Silymarin ascending multiple oral dosing phase I study in noncirrhotic patients with chronic hepatitis C. J Clin Pharmacol. 2010;50(4):434-49. doi:10.1177/0091270009347475.

34. Zhao J, Agarwal R. Tissue distribution of silibinin, the major active constituent of silymarin, in mice and its association with enhancement of phase II enzymes: implications in cancer chemoprevention. Carcinogenesis. 1999;20(11):2101-8.

35. Ei.Christodoulou IAK, Kostomitsopoulos N, Balafas E, Archontaki E, Dokoumetzidis A, Valsami G. Pharmacokinetics of silibinin in mice tissues and serum after peros and intravenous administration as a HP-ß-CD lyophilized product. Poster: Drug/Disease modeling - Absorption \& PBPK. 2014. p. 23.

36. Hoh C, Boocock D, Marczylo T, Singh R, Berry DP, Dennison AR, et al. Pilot study of oral silibinin, a putative chemopreventive agent, in colorectal cancer patients: silibinin levels in plasma, colorectum, and liver and their pharmacodynamic consequences. Clinical cancer research : an official journal of the American Association for Cancer Research. 2006;12(9):294450. doi:10.1158/1078-0432.ccr-05-2724.

37. Flaig TW, Glode M, Gustafson D, van Bokhoven A, Tao Y, Wilson S, et al. A study of high-dose oral silybin-phytosome followed by prostatectomy in patients with localized prostate cancer. Prostate. 2010;70(8):848-55. doi:10.1002/pros.21118

38. Kock K, Xie Y, Hawke RL, Oberlies NH, Brouwer KL. Interaction of silymarin flavonolignans with organic anion-transporting polypeptides. Drug metabolism and disposition: the biological fate of chemicals. 2013;41(5): 958-65. doi:10.1124/dmd.112.048272.

39. Han Y, Guo D, Chen Y, Tan ZR, Zhou HH. Effect of continuous silymarin administration on oral talinolol pharmacokinetics in healthy volunteers. Xenobiotica; the fate of foreign compounds in biological systems. 2009; 39(9):694-9. doi:10.1080/00498250903060077.

40. Doehmer J, Tewes B, Klein KU, Gritzko K, Muschick H, Mengs U. Assessment of drug-drug interaction for silymarin. Toxicology in vitro : an international journal published in association with BIBRA. 2008;22(3):610-7. doi:10.1016/j.tiv.2007.11.020.
41. Doehmer J, Weiss G, McGregor GP, Appel K. Assessment of a dry extract from milk thistle (Silybum marianum) for interference with human liver cytochrome-P450 activities. Toxicology in vitro : an international journal published in association with BIBRA. 2011;25(1):21-7. doi:10.1016/j.tiv.2010.09.001.

42. Fuhr U, Beckmann-Knopp S, Jetter A, Luck H, Mengs U. The effect of silymarin on oral nifedipine pharmacokinetics. Planta Med. 2007;73(14): 1429-35. doi:10.1055/s-2007-990256.

43. Brantley SJ, Oberlies NH, Kroll DJ, Paine MF. Two flavonolignans from milk thistle (Silybum marianum) inhibit CYP2C9-mediated warfarin metabolism at clinically achievable concentrations. The Journal of pharmacology and experimental therapeutics. 2010;332(3):1081-7. doi:10.1124/jpet.109.161927.

44. Brantley SJ, Gufford BT, Dua R, Fediuk DJ, Graf TN, Scarlett YV, et al. Physiologically based pharmacokinetic modeling framework for quantitative prediction of an herb-drug interaction. CPT: pharmacometrics \& systems pharmacology. 2014;3, e107. doi:10.1038/psp.2013.69.

45. Parasassi T, Martellucci A, Conti F, Messina B. Drug-membrane interactions: silymarin, silibyn and microsomal membranes. Cell Biochem Funct. 1984; 2(2):85-8. doi:10.1002/cbf.290020206

46. Wu DF, Peng RX, Ye LP, Yu P. [The effects of silymarin on hepatic microsomal and mitochondrial membrane fluidity in mice]. Zhongguo Zhong yao za zhi $=$ Zhongguo zhongyao zazhi $=$. China journal of Chinese materia medica. 2003;28(9):870-2.

47. Roberti R, Mozzi R, De Medio GE, Francescangeli E, Porcellati G. The activity of silymarin on membrane-bound phospholipid metabolism in brain and liver tissues of the rat. Pharmacol Res Commun. 1973:5(3):249-57.

48. Vladimir-Knezevic S, Cvijanovic O, Blazekovic B, Kindl M, Stefan MB, Domitrovic R. Hepatoprotective effects of Micromeria croatica ethanolic extract against CCl4-induced liver injury in mice. BMC complementary and alternative medicine. 2015;15:233. doi:10.1186/s12906-015-0763-8.

49. Podder B, Kim YS, Zerin T, Song HY. Antioxidant effect of silymarin on paraquat-induced human lung adenocarcinoma A549 cell line. Food and chemical toxicology : an international journal published for the British Industrial Biological Research Association. 2012;50(9):3206-14. doi:10.1016/j. fct.2012.06.007.

50. Basiglio CL, Sanchez Pozzi EJ, Mottino AD, Roma MG. Differential effects of silymarin and its active component silibinin on plasma membrane stability and hepatocellular Iysis. Chem Biol Interact. 2009;179(2-3):297-303. doi:10. 1016/j.cbi.2008.12.008.

51. Kang JS, Jeon YJ, Kim HM, Han SH, Yang KH. Inhibition of inducible nitricoxide synthase expression by silymarin in lipopolysaccharide-stimulated macrophages. The Journal of pharmacology and experimental therapeutics. 2002;302(1):138-44.

52. Vecera AZ R, Orolin J, Skottova N, Anzenbacher P. The effect of silymarin on expression of selected $A B C$ transporters in the rat. Vet Med. 2011;56(2): 59-62.

53. Machicao F, Sonnenbichler J. Mechanism of the stimulation of RNA synthesis in rat liver nuclei by silybin. Hoppe-Seyler's Zeitschrift fur physiologische Chemie. 1977;358(2):141-7.

54. Clichici S, Olteanu D, Nagy AL, Oros A, Filip A, Mircea PA. Silymarin inhibits the progression of fibrosis in the early stages of liver injury in CCl(4)-treated rats. J Med Food. 2015;18(3):290-8. doi:10.1089/jmf.2013. 0179.

55. Trappoliere M, Caligiuri A, Schmid M, Bertolani C, Failli P, Vizzutti F, et al. Silybin, a component of sylimarin, exerts anti-inflammatory and antifibrogenic effects on human hepatic stellate cells. J Hepatol. 2009;50(6): 1102-11. doi:10.1016/j.jhep.2009.02.023.

56. Kim M, Yang SG, Kim JM, Lee JW, Kim YS, Lee Jl. Silymarin suppresses hepatic stellate cell activation in a dietary rat model of non-alcoholic steatohepatitis: analysis of isolated hepatic stellate cells. International journal of molecular medicine. 2012;30(3):473-9. doi:10.3892/ijmm.2012.1029.

57. Iwakami S, Misu H, Takeda T, Sugimori M, Matsugo S, Kaneko S, et al. Concentration-dependent dual effects of hydrogen peroxide on insulin signal transduction in H4IIEC hepatocytes. PLoS One. 2011;6(11):e27401. doi: 10.1371/journal.pone.0027401.

58. Tormos AM, Talens-Visconti R, Nebreda AR, Sastre J. p38 MAPK: a dual role in hepatocyte proliferation through reactive oxygen species. Free Radic Res. 2013:47(11):905-16. doi:10.3109/10715762.2013.821200.

59. Dingermann Th HR, Zündorf I. (Editors). Pharmazeutische Biologie: Molekulare Grundlagen und klinische Anwendung. Springer Verlag Berlin Heidelberg. Springer Ed. 2002 113. ISBN 978-3-642-55943-3. 
60. Schattenberg JM, Czaja MJ. Regulation of the effects of CYP2E1-induced oxidative stress by JNK signaling. Redox biology. 2014;3:7-15. doi:10.1016/j. redox.2014.09.004.

61. Ceni E, Mello T, Galli A. Pathogenesis of alcoholic liver disease: role of oxidative metabolism. World J Gastroenterol. 2014;20(47):17756-72. doi:10. 3748/wjg.v20.i47.17756.

62. Lin JC, Peng YJ, Wang SY, Young TH, Salter DM, Lee HS. Role of the sympathetic nervous system in carbon tetrachloride-induced hepatotoxicity and systemic inflammation. PLoS One. 2015;10(3):e0121365. doi:10.1371/ journal.pone.0121365.

63. Mantena SK, King AL, Andringa KK, Landar A, Darley-Usmar V, Bailey SM. Novel interactions of mitochondria and reactive oxygen/nitrogen species in alcohol mediated liver disease. World J Gastroenterol. 2007;13(37):4967-73.

64. Robin MA, Sauvage I, Grandperret T, Descatoire V, Pessayre D, Fromenty B. Ethanol increases mitochondrial cytochrome P450 2E1 in mouse liver and rat hepatocytes. FEBS Lett. 2005;579(30):6895-902. doi:10.1016/j.febslet.2005. 11.029 .

65. Chen XH, Hu YM, Liao YQ. Protective effects of tetrandrine on CCl4-injured hepatocytes. Zhongguo yao li xue bao = Acta pharmacologica Sinica. 1996; 17(4):348-50.

66. Waller RL, Glende Jr EA, Recknagel RO. Carbon tetrachloride and bromotrichloromethane toxicity. Dual role of covalent binding of metabolic cleavage products and lipid peroxidation in depression of microsomal calcium sequestration. Biochem Pharmacol. 1983;32(10):1613-7.

67. Abdel Salam OM, Sleem AA, Shafee N. Hepatoprotective effects of the nitric oxide donor isosorbide-5-mononitrate alone and in combination with the natural hepatoprotectant, silymarin, on carbon tetrachloride-induced hepatic injury in rats. Inflammopharmacology. 2010;18(2):87-94. doi:10.1007/ s10787-009-0027-7.

68. Singh Gaaminepreet RG. Pyare Lal Sharma. Pharmacological potential of silymarin in combination with hepatoprotective plants against experimental hepatotoxicity in rats Asian. Journal of Pharmaceutical and Clinical Research. 2012;5:Suppl 1. ISSN - 0974-2441.

69. Saller R, Brignoli R, Melzer J, Meier R. An updated systematic review with meta-analysis for the clinical evidence of silymarin. Forschende Komplementarmedizin (2006). 2008;15(1):9-20, doi:10.1159/000113648.

70. Di Mario FR, Melzer J, Meier R. Die Wirkung von Silymarin auf Leberfunktionsproben bei Patienten mit alkoholbedingter Lebererkrankung. Doppelblindstudie. In: Di Ritis F, Csomos G, Braatz R, editors. Der toxischmetabolische Leberschaden Lübeck: Hansisches Verlagskontor. 1981. p. 54-8.

71. Salmi HASS. Effect of silymarin on chemical, functional, and morphological alterations of the liver. A double-blind controlled study. Scand J Gastroenterol. 1982;17:517-21.

72. Feher JDG, Muzes G, Lang I, Niederland V, Nekam K, Karteszi M. Liverprotective action of silymarin therapy in chronic alcoholic liver diseases] Silymarin kezeles majvedo hatasa idult alkoholos majbetegsegben. Orv Hetil. 1989;130:2723-7.

73. Muzes G, Deak G, Lang I, Nekam K, Niederland V, Feher J. Effect of silimarin (Legalon) therapy on the antioxidant defense mechanism and lipid peroxidation in alcoholic liver disease (double blind protocol). Orv Hetil. 1990;131(16):863-6.

74. Dyson JK, Anstee QM, McPherson S. Non-alcoholic fatty liver disease: a practical approach to diagnosis and staging. Frontline gastroenterology. 2014;5(3):211-8. doi:10.1136/flgastro-2013-100403.

75. Schuppan D, Schattenberg JM. Non-alcoholic steatohepatitis: pathogenesis and novel therapeutic approaches. J Gastroenterol Hepatol. 2013;28 Suppl 1: 68-76. doi:10.1111/jgh.12212

76. Ratziu V, Goodman Z, Sanyal A. Current efforts and trends in the treatment of NASH. J Hepatol. 2015;62(1 Suppl):S65-75. doi:10.1016/j.jhep.2015.02.041.

77. Brunt EM, Tiniakos DG. Histopathology of nonalcoholic fatty liver disease. World J Gastroenterol. 2010;16(42):5286-96.

78. Weinmann A, Alt Y, Koch S, Nelles C, Duber C, Lang H, et al. Treatment and survival of non-alcoholic steatohepatitis associated hepatocellular carcinoma. BMC Cancer. 2015;15:210. doi:10.1186/s12885-015-1197-x.

79. Konrad D, Wueest $\mathrm{S}$. The gut-adipose-liver axis in the metabolic syndrome. Physiology (Bethesda, Md). 2014;29(5):304-13. doi:10.1152/physiol.00014. 2014

80. Dai $X$, Wang B. Role of gut barrier function in the pathogenesis of nonalcoholic Fatty liver disease. Gastroenterol Res Pract. 2015;2015:287348. doi:10.1155/2015/287348.
81. Schnabl B, Brenner DA. Interactions between the intestinal microbiome and liver diseases. Gastroenterology. 2014;146(6):1513-24. doi:10.1053/j.gastro. 2014.01.020

82. Zhu L, Baker RD, Baker SS. Gut microbiome and nonalcoholic fatty liver diseases. Pediatr Res. 2015;77(1-2):245-51. doi:10.1038/pr.2014.157.

83. Engstler AJ, Aumiller $T$, Degen $C$, Durr M, Weiss E, Maier IB, et al. Insulin resistance alters hepatic ethanol metabolism: studies in mice and children with non-alcoholic fatty liver disease. 2015. doi:10.1136/ gutjnl-2014-308379.

84. Seki E, Schnabl B. Role of innate immunity and the microbiota in liver fibrosis: crosstalk between the liver and gut. J Physiol. 2012;590(Pt 3):447-58 doi:10.1113/jphysiol.2011.219691.

85. Luther JGJ, Khalili H, Dave M, Bale SS, Jindal R, Motola DL, et al. Hepatic injury in nonalcoholic steatohepatitis contributes to altered intestinal permeability. Cellular and Molecular Gastroenterology and Hepatology. 2015;1(2):222-32. e2. doi:10.1016/j.jcmgh.2015.01.001.

86. Gusdon AM, Song KX, Qu S. Nonalcoholic fatty liver disease: pathogenesis and therapeutics from a mitochondria-centric perspective. Oxidative Med Cell Longev. 2014;2014:637027. doi:10.1155/2014/637027.

87. Esmaily HH-TA, Rahimian R, Khorasani R, Baeeri M, Barazesh-Morgani A, Yasa $\mathrm{N}$, et al. On the benefits of silymarin in murine colitis by improving balance of destructive cytokines and reduction of toxic stress in the bowel cells. Central European Journal of Biology. 2009;4(2):204-13.

88. Sasu A, Herman H, Mariasiu T, Rosu M, Balta C, Anghel N, et al. Protective effects of silymarin on epirubicin-induced mucosal barrier injury of the gastrointestinal tract. Drug Chem Toxicol. 2015;38(4):442-51. doi:10.3109/ 01480545.2014.992072.

89. Demir M, Amanvermez R, Kamali Polat A, Karabicak I, Cinar H, Kesicioglu T, et al. The effect of silymarin on mesenteric ischemia-reperfusion injury. Medical principles and practice : international journal of the Kuwait University, Health Science Centre. 2014;23(2):140-4. doi:10.1159/000356860.

90. Huilgol SJMG. Gastroprotective role of bioflavonoid silymarin in animal model of acute cold-restraint stress induced gastric ulceration. Al Ameen Journal of Medical Sciences. 2013;6(1):40.

91. Rastegarpanah M, Malekzadeh R, Vahedi H, Mohammadi M, Elahi E, Chaharmahali $\mathrm{M}$, et al. A randomized, double blinded, placebo-controlled clinical trial of silymarin in ulcerative colitis. Chinese journal of integrative medicine. 2012. doi:10.1007/s11655-012-1026-x.

92. Hutchinson C, Bomford A, Geissler CA. The iron-chelating potential of silybin in patients with hereditary haemochromatosis. Eur J Clin Nutr. 2010;64(10): 1239-41. doi:10.1038/ejcn.2010.136.

93. Schattenberg JM, Galle PR. Animal models of non-alcoholic steatohepatitis: of mice and man. Digestive diseases (Basel, Switzerland). 2010;28(1):247-54. doi:10.1159/000282097.

94. Bian Z, Ma X. Liver fibrogenesis in non-alcoholic steatohepatitis. Front Physiol. 2012;3:248. doi:10.3389/fphys.2012.00248.

95. Salamone F, Galvano F, Cappello F, Mangiameli A, Barbagallo I, Li VG. Silibinin modulates lipid homeostasis and inhibits nuclear factor kappa B activation in experimental nonalcoholic steatohepatitis. Translational research : the journal of laboratory and clinical medicine. 2012;159(6):47786. doi:10.1016/j.trsl.2011.12.003.

96. Pais P, D'Amato M. In vivo efficacy study of milk thistle extract (ETHIS-094) in STAM model of nonalcoholic steatohepatitis. Drugs in R\&D. 2014;14(4): 291-9. doi:10.1007/s40268-014-0068-2.

97. Salamone F, Galvano F, Marino Gammazza A, Paternostro C, Tibullo D, Bucchieri $F$, et al. Silibinin improves hepatic and myocardial injury in mice with nonalcoholic steatohepatitis. Digestive and liver disease : official journal of the Italian Society of Gastroenterology and the Italian Association for the Study of the Liver. 2012;44(4):334-42. doi:10.1016/j.dld.2011.11.010.

98. Hajiani EHSJ. Comparison of therapeutic effects of silymarin and vitamin $\mathrm{E}$ in nonalcoholic fatty liver disease: results of an open labele, prospective, randomized study Jundishapur. Journal of Natural Pharmaceutical Products. 2009;4(1):8-14.

99. Masoodi MRA, Panahian M, Vojdanian M. Effects of silymarin on reducing liver aminotransferases in patients with nonalcoholic fatty liver diseases. GOVARESH. 2013;18(3):181-5.

100. Hashemi SJHE, Sardabi EH. A placebo-controlled trial of silymarin in patients with nonalcoholic fatty liver disease. Hepat Mon. 2009;9(4):265-70.

101. Solhi H, Ghahremani R, Kazemifar AM, Hoseini YZ. Silymarin in treatment of non-alcoholic steatohepatitis: a randomized clinical trial. Caspian journal of internal medicine. 2014;5(1):9-12. 
102. Hajiaghamohammadi AA, Ziaee A, Oveisi S, Masroor H. Effects of metformin, pioglitazone, and silymarin treatment on non-alcoholic fatty liver disease: a randomized controlled pilot study. Hepat Mon. 2012;12(8):e6099. doi:10. 5812/hepatmon.6099.

103. Schuppan D, Afdhal NH. Liver cirrhosis. Lancet (London, England). 2008; 371(9615):838-51. doi:10.1016/s0140-6736(08)60383-9.

104. De Minicis SMM, Saccomanno S, Rychlicki C, Agostinelli L, Trozzi L, Benedetti A, et al. Cellular and molecular mechanisms of hepatic fibrogenesis leading to liver cancer. Transl Gastrointest Cancer. 2012;1:88-94. doi:10.3978/j.issn. 2224-4778.2011.12.05.

105. Bataller R, Brenner DA. Liver fibrosis. J Clin Invest. 2005;115(2):209-18. doi:10. $1172 /$ jci24282.

106. Hayashi H, Sakai T. Animal models for the study of liver fibrosis: new insights from knockout mouse models. American journal of physiology Gastrointestinal and liver physiology. 2011;300(5):G729-38. doi:10.1152/ajpgi. 00013.2011

107. Xu J, Liu X, Koyama Y, Wang P, Lan T, Kim IG, et al. The types of hepatic myofibroblasts contributing to liver fibrosis of different etiologies. Front Pharmacol. 2014;5:167. doi:10.3389/fphar.2014.00167.

108. Liu Y, Meyer C, Xu C, Weng H, Hellerbrand C, ten Dijke P, et al. Animal models of chronic liver diseases. American journal of physiology Gastrointestinal and liver physiology. 2013;304(5):G449-68. doi:10.1152/ajpgi. 00199.2012.

109. Jeong DH, Lee GP, Jeong WI, Do SH, Yang HJ, Yuan DW, et al. Alterations of mast cells and TGF-beta1 on the silymarin treatment for $\mathrm{CCl}(4)$-induced hepatic fibrosis. World J Gastroenterol. 2005;11(8):1141-8.

110. Chen IS, Chen YC, Chou CH, Chuang RF, Sheen LY, Chiu CH. Hepatoprotection of silymarin against thioacetamide-induced chronic liver fibrosis. J Sci Food Agric. 2012;92(7):1441-7. doi:10.1002/jsfa.4723.

111. Shaker ME, Zalata KR, Mehal WZ, Shiha GE, Ibrahim TM. Comparison of imatinib, nilotinib and silymarin in the treatment of carbon tetrachlorideinduced hepatic oxidative stress, injury and fibrosis. Toxicol Appl Pharmacol. 2011;252(2):165-75. doi:10.1016/j.taap.2011.02.004.

112. Ezhilarasan D, Karthikeyan S, Vivekanandan P. Ameliorative effect of silibinin against $\mathrm{N}$-nitrosodimethylamine-induced hepatic fibrosis in rats. Environ Toxicol Pharmacol. 2012;34(3):1004-13. doi:10.1016/j.etap.2012.07.004

113. Li CC, Hsiang CY, Wu SL, Ho TY. Identification of novel mechanisms of silymarin on the carbon tetrachloride-induced liver fibrosis in mice by nuclear factor-kappaB bioluminescent imaging-guided transcriptomic analysis. Food and chemical toxicology : an international journal published for the British Industrial Biological Research Association. 2012;50(5):1568-75. doi:10.1016/j.fct.2012.02.025.

114. Asrani SK, Larson JJ, Yawn B, Therneau TM, Kim WR. Underestimation of liver-related mortality in the United States. Gastroenterology. 2013;145(2): 375-82. doi:10.1053/j.gastro.2013.04.005. e1-2.

115. Ferenci P, Dragosics B, Dittrich H, Frank H, Benda L, Lochs $H$, et al. Randomized controlled trial of silymarin treatment in patients with cirrhosis of the liver. J Hepatol. 1989;9(1):105-13.

116. Pares APR, Torres M, Caballeria J, Viver JM, Acero D, Panes J, et al. Effects of silymarin in alcoholic patients with cirrhosis of the liver: results of a controlled, double-blind, randomized and multi-center trial. J Hepatol. 1998; 28:615-21.

117. Rambaldi A, Jacobs BP, Gluud C. Milk thistle for alcoholic and/or hepatitis B or $C$ virus liver diseases. The Cochrane database of systematic reviews. 2007; 4:Cd003620. doi:10.1002/14651858.CD003620.pub3.

118. Grabhorn E, Nielsen D, Hillebrand G, Brinkert F, Herden U, Fischer L, et al. Successful outcome of severe Amanita phalloides poisoning in children. Pediatr Transplant. 2013;17(6):550-5. doi:10.1111/petr.12108.

119. Mengs U, Pohl RT, Mitchell T. Legalon(R) SIL: the antidote of choice in patients with acute hepatotoxicity from amatoxin poisoning. Curr Pharm Biotechnol. 2012;13(10):1964-70.

120. Roberts DM, Hall MJ, Falkland MM, Strasser SI, Buckley NA. Amanita phalloides poisoning and treatment with silibinin in the Australian Capital Territory and New South Wales. The Medical journal of Australia. 2013; 198(1):43-7

121. Ward J, Kapadia K, Brush E, Salhanick SD. Amatoxin poisoning: case reports and review of current therapies. The Journal of emergency medicine. 2013; 44(1):116-21. doi:10.1016/j.jemermed.2012.02.020.

122. Kassem LM, Abdelrahim ME, Naguib HF. Investigating the efficacy and safety of silymarin in management of hyperbilirubinemia in neonatal jaundice. Med-Science. 2013;2(2):575-90.
123. Ladas EJ KD, Oberlies NH, Cheng B, Hughes D, Rheingold SR, Kelly KM. A randomized controlled, double-blind pilot study of milk thistle for the treatment of hepatotoxicity in childhood acute lymphoblastic leukemia (ALL). Cancer. 2010;116(2):506-13. doi:10.1002/cncr.24723.

124. Pellegrini L, Belcaro G, Dugall M, Hu S, Gizzi G, Corsi M, et al. Management of functional, hepatic damage after chemotherapy with Liverubin (pharmastandard silymarin). Minerva gastroenterologica e dietologica. 2015.

125. Hagag AA. Therapeutic value of combined therapy with Deferiprone and Silymarin as iron chelators in Egyptian Children with Beta Thalassemia major. Infectious disorders drug targets. 2015.

126. Moayedi Esfahani BA, Reisi N, Mirmoghtadaei M. Evaluating the safety and efficacy of silymarin in beta-thalassemia patients: a review. Hemoglobin. 2015;39(2):75-80. doi:10.3109/03630269.2014.1003224.

127. Koh WP, Robien K, Wang R, Govindarajan S, Yuan JM, Yu MC. Smoking as an independent risk factor for hepatocellular carcinoma: the Singapore Chinese Health Study. Br J Cancer. 2011;105(9):1430-5. doi:10.1038/bjc.2011.360.

128. Saab S, Mallam D, Cox 2nd GA, Tong MJ. Impact of coffee on liver diseases: a systematic review. Liver international : official journal of the International Association for the Study of the Liver. 2014;34(4):495-504. doi:10.1111/liv. 12304.

129. Nichols Jr T. A review of fatty liver/NASH and liver cirrhosis: genetics, prevention, nutritional, behavioral modification, exercise, pharmaceutical, biophysics and biotech therapy. J Liver. 2013;3:144. doi:10.4172/2167-0889. 1000144.

130. Sharma $\mathrm{V}, \mathrm{McNeill} J \mathrm{H}$. To scale or not to scale: the principles of dose extrapolation. Br J Pharmacol. 2009;157(6):907-21. doi:10.1111/j.1476-5381. 2009.00267.x.

131. Mahli A, Koch A, Czech B, Peterburs P, Lechner A, Haunschild J, et al. Hepatoprotective effect of oral application of a silymarin extract in carbon tetrachloride-induced hepatotoxicity in rats. Clinical Phytoscience. 2015;1(5): 5. doi:10.1186/s40816-015-0006-z.

132. Trinchet JC, Coste T, Levy VG, Vivet F, Duchatelle V, Legendre C, et al. Treatment of alcoholic hepatitis with silymarin. A double-blind comparative study in 116 patients. Gastroenterol Clin Biol. 1989;13(2):120-4.

133. Bunout D, Hirsch S, Petermann M, de la Maza MP, Silva G, Kelly M, et al. Controlled study of the effect of silymarin on alcoholic liver disease. Rev Med Chil. 1992;120(12):1370-5.

134. Lucena MI, Andrade RJ, de la Cruz JP, Rodriguez-Mendizabal M, Blanco E, Sanchez de la Cuesta F. Effects of silymarin MZ-80 on oxidative stress in patients with alcoholic cirrhosis. Results of a randomized, double-blind, placebo-controlled clinical study. Int J Clin Pharmacol Ther. 2002;40(1):2-8

\section{Submit your manuscript to a SpringerOpen ${ }^{\circ}$ journal and benefit from:}

- Convenient online submission

- Rigorous peer review

- Immediate publication on acceptance

- Open access: articles freely available online

- High visibility within the field

- Retaining the copyright to your article

Submit your next manuscript at $>$ springeropen.com 